\title{
(IN-)VISIBLE LIVING SPACE AS THE EDUCATIONAL SPACE DREAMS-SELF-NARRATION IN BIOGRAPHIES OF ELDERLY PEOPLE
}

\author{
Malgorzata Piasecka \\ Jan Dlugosz University in Czestochowa, Poland
}

\begin{abstract}
The objective of the paper is providing an answer to the question about educational and causative dimensions of dreams-self-narrations in biography of senior individuals. In the theoretical part, the authoress focuses on analyses concerning respectively: (in-)visible living space, trajectory of individual biographies and characteristics of dreams as self-narrations in structuring one's own biography. In the methodological part, the authoress presents the assumptions of a research project based on the biographical method by applying narrative interviews. In the empirical part, results of vertical and horizontal analyses are presented in the form of the worked out biographical profiles in the context of highlighted areas of study.
\end{abstract}

Keywords: biography, education, (in-)visible living space, dreams-self-narration, third age.

\section{Introduction}

Dreams must be narrated. They must stop being kept silent and they must be added to discourses which creatively create the (in-)visible space. It is a reflection creating circumstances for studying educational and causative dimensions of dreaming in the course of biography of an individual, particularly in relation to the elderly people. This is the objective of this paper. The methodology of qualitative studies and the biographical method have been applied as the basic research strategy. From the point of view of modern humanistic metaformation, there is a noticeable need for narrative studies with reference to the issue discussed in this paper. The ideas of the authoress concerning the issue are organised by the following meta - level questions:

Firstly - What should be done, in order to sustain dreams, which as the signs of spiritual (symbolic) life create the (in-)visible living space of each human individual? In this dimension, the fundamental reference is the idea of aesthetisation of the world (Foucault, 2000), i.e. one's concern with oneself, and with other individuals, existential awakening making one sensitive to the quality of one's own and other people's biography, creating oneself and the world as a work of art through self-observation, reflections, creation of new ideas when dreaming about oneself and the world, treating oneself and the world as a kind of research laboratory of human existence (Kundera, 1991).

Secondly - How should it be done? Are there any definite tools and methods of their use, which would allow effective struggle for oneself and others, for a possible and desired world? In this dimension, the most important element is language as the most important tool used to build oneself, and other 
individuals. Self-narrations are stories about series of temporal events - I tell stories, therefore I am. It is necessary to teach the ability to express oneself as an active element in the background of nature and culture; it is necessary to teach meditation on the texts of culture and putting words into action (Janion, 1996).

\section{(In-)Visible Living Space}

Living space of an individual is fully determined by many different factors. The first factor covers a set of mutual relations among coexisting objects, in which occurrences and processes on which everyday activities of individual people are based. Another factor covers the individuals' close social milieu, in which they function daily. i.e. their world consisting of other people (family, professional, neighbourhood, friend settings). The third factor covers matters and objects of physical nature, which determine specificity and attractiveness of the space. Finally, the fourth factor of an individual's living space, which covers the world of his or her spirituality (not only in the sphere of religion), the world of their internal experiences, emotions, desires, dreams, and aesthetic impressions (Semków, 2000).

This paper treats about the living space of the elderly people, who are at present the largest proportions of European nations. The deteriorating status of this social group and the processes of exclusion provoke reflection and attempts to show possible educational paths facilitating their further self-development. One should assume that full experiencing of their living space by the third age people is an indicator of their well-being and, consequently, of their better status. The dimensions of well-being are: self-acceptance, control of one's environment, autonomy, positive relations with other people, personal development (Czapiński, 2005, p. 153). Personal development, the key element of well- being, is an ability to make continuous use of one's potential, which is necessary to implement of the purpose of one's life, i.e. searching for and finding the sense of life in confrontation with adversities of fate during one's own biography (ibid., pp. 153-156).

The concept of the (in-)visible living space introduced here by the authoress as the key concept requires an explanation. Taking into account the dimensions of space mentioned above, there is no escaping simple dichotomic division into: material (physical), or visible space and the spiritual (symbolic), or invisible space. In the holistic approach to the space - man relation, negation of the nature - culture dualism is negated. The negation gives rise to the phenomenon known as "culturization of nature and naturalization of culture" (Burszta \&Kuligowski, 1998, p. 165). A similar idea is expressed by Florian Znaniecki when he stresses that "hundreds of thousands of cultural life accumulated such an enormous number of customs and traditions, that a human being is absolutely unable to perceive or imagine their other nature than the one that he or she views through of culture" (Hałas, 1991, p.16). Peter L. Berger and 
Thomas Luckmann present evidence how important the subjective meanings resulting from the internal nature of everyday reality are for individual people. "It is a world which is created in their thoughts and actions and due to those thoughts and activities remains as their real world" (Berger, Luckmann, 2010, p. 50). What, in fact, is the (in)visible space then? Divisions into the external (visible) and internal (invisible) have always been of symbolic nature, because each work had been created in the inventor's mind before it assumed its physical form). S. Covey (1998) calls the process building with a vision of the end, which is based on the assumption that everything is created twice, first mentally in an individual's mind and then physically in reality. "A world created by an individual is always a world in which a creative idea interweaves with a material in which it was materialized, and it is a continuous world, i.e. the world in which there are no fundamental gaps between the most abstract ideas and everyday objects" (Sroczyński, 2006, p. 35). The concept of an "open universe" (Popper, 1996, p. 25), entangled in relationships of "three worlds" (ibid., p. 20), is a corresponding perspective. What worlds are they? World $1-$ is the physical world, whereas World 2 - is the world of all conscious, and probably unconscious, experiences and, finally, World 3 - the world of objective figments of human mind (Ibid., p.21). And the relations between them? We cannot understand World 2, i.e. the world inhabited by our mental states if we do not realize that its basic function is to create objects in the World 3 and be subject to their influence. World 2 interacts not only with World 1, as Descartes assumed, but also with World 1; and the objects of World 3 can only interact with World 1 through World 2, which acts as an intermediary link between the two (ibid., p. 17).

From this point of view, the (in-)visible space, which introduces social pedagogues into the circle of a subjective world of an individual, becomes an interesting research area. Cognition of this world is a humanistic cognition, which requires insight, intuition, empathy, imagination of an explorer in deciphering, understanding and interpreting symbols. The (in-)visible space is "a personal, intimate world of individuals, which to a considerable degree determines their attitude towards their environment and themselves, their role and lifestyle, creates trends and content of their activities" (Sroczyński, 2006, p.37). Individuals, like cartographers, first create maps in their minds and then form their living space according to the maps. The space is always "educational". "Life is going on within that space", decisions are taken, meanings are revealed, dreams are realized. The space is characterized by changes and, corresponding to each life activity of an individual, create him or her in the same way that he or she creates the space as a result of his or her incessant interferences and more or less spectacular transformations. It is safe to say that our spaces treat us with mutuality (Mendel, 2006). Spaces educate us. 


\section{Trajectory of an individual's biography}

Individuals always set off from a place where they are rooted and wander around the world building their biographies. In traditional communities, individual settling habits have always been accompanied by the rites of passage marking the sense of human existence from the moment of birth, through social maturing, marriage, labour, until the inevitable death, excluding him or her for ever from the community he/she had been a member of. In our times, qualitative changes in a biography are marked mainly with the moments determined by the logic of the labour market and thus - the level of possibly high consumption. Then comes degradation of the spiritual (symbolic) living space. Instead of classical biographies, always individualized in one way or another, in spite of the fact that they were contained in a general pattern of place and time, there appears a phenomenon which is characteristic for modern liberal capitalist economy. Urlich Beck calls them institutionalized biographies connected with a performed profession and place of work. The pattern of such biography is set by three major elements - education, labour and retirement pension (Beck, 2004). According to an institutionalized biography "people are as replaceable as objects and serve us as long as they seem to be useful, [...], there is no need to "fix" them or be overfamiliar with them" (Burszta, 2008).

In the case of elderly people, their retirement is traditionally understood as the moment of passing into another qualitative dimension. Regrettably, it is often connected with the pessimistic image of old age. "Pensioning people off makes them old not only socially, but it may make them feel old physically, psychologically and generally unwanted" (Semków, 2000, p. 29). Moreover, in the situation of the binding institutionalized biography each individual path of life is accompanied by growing uncertainty and risk. After losing the sense of security, individuals face crisis and find themselves floating. The theoretical concept of floating formulated by Agnieszka Bron (2000) is understood as a state of anguish and dislocation, and it is connected with the difficulty of taking vital decisions. Can retired people be in the state of floating? The conclusion indicates that they can, because in many cases it is accompanied by a sense of social, emotional, and/or intellectual crisis. Then, people lose the sense of secure intimacy, which was provided by being in traditional relationships. As a result, "the trajectory of an individual's life depends more and more often on his/her individual plans, choices" (Nowak-Dziemianowicz, 2011, p. 43). Therefore, "the situation of floating should be treated as a process of learning, as open doors of experience, not as static rites of passage" (ibid., p. 44). Losing their security, individuals re-analyse their motivational objectives, modify their plans, as well as set their strategies of learning. Self-education becomes a task, an imperative, an obligation. At the beginning, they chaotically take their first steps, learning to diagnose the experienced events (Słowik, 2012). They become more and more aware of their "out of the ordinary everyday life" (Siarkiewicz, 
2010, p. 273) and do everything in their power to create, put together, "conjure up", dream up "their own „familiar" everyday routine. Peter Jarvis (2006) calls this type of acquiring knowledge existential learning. In his opinion, "being" and taking action by individuals should occupy the central place in human learning. At the same time, they notice that learning is a process and it is not important "what" the learner has learnt, but "what has been started" as an effect of human action, thinking and one's own experience of "being present in the world". Such nature of educational activity can be described as provocative education, in which one does not only "pass" through experiences, but also arouses, provokes, kindles, seeks their educational sense (Łukaszewicz, 2012). Hence, an elderly individual, who is in the situation of floating is expected to provoke biographical learning, which is independent and self-creative, and which is meant to result in an intentional, prospective planning of the course of one's own life and creative implementation of such plans. "Soul biography" (Lani-Bayle, 2014), which is an educational path of looking for the way to oneself, to recognition and experiencing one's own fortune should be set as an existential obligation of each individual, in contrast to the institutionalized biography, which often results in floating and helplessness. We should learn to be ourselves, and unlearn to like other people, unlearn to be nothing, unlearn to imitate other people's voices, unlearn to recognise other people's faces to be our own. We should learn to live our own lives, recognise our own destination, implement our desires, dreams and leave their creative marks in our biography (ibid., p. 21).

\section{Dreams as self-narrations in formation of one's biography}

One of the most import ant transformations of the modern liberal arts was called narrativistic turnabout, which means that stories started to be attributed a fundamental role in human culture and mentality. Narration was recognised to the basic structure organizing experience and understanding. One can repeat after M. Bachtin that "novelizing of almost all areas of spiritual life of man has become an obvious process since then" ( Burzyńska \& Markowski, 2006, p. 160). In philosophy, ontological basis for the narrativistic theory of identity were defined by M. Heidegger. Understanding that had a narrative structure was a condition for human existence, which means that narration and human living can be treated as equivalent processes. Owing to the ideal of narration philosophical thought created conditions for transition from substantialist to dynamic perspective of the subject, "from the Cartesian I think, therefore I am to the narrative I narrate, therefore I am" (ibid., p. 33).

The essential fact for the reasoning conducted here is that narrative properties are also attributed to the mental processes in which we plan our future actions. Such reasoning is a consequence of assuming the theses of the narrativistic turnabout, which in its most radical conceptions stated that "even 
human mind functions in a narrative way"(ibid., p. 28). Dreams as manifestations of the spiritual life of an individual are self-narrations. They should not be treated as an aesthetic invention, but as a primary act of mind transferred from art to life, because "in order to live, we create stories about ourselves and others referring to both, our personal as well as social past and future" (ibid., p. 32). Thus, in the narrativistic perspective, life together with dreams is understood as a field for constructive action, and narration as a creative process of formation of our biography. "Telling stories is ageless, widely cultural, it is always present, like life (Barthes, 1968, p. 328). When accepting the thesis that dreams are of auto-narrative nature, we emphasize at the very beginning the fact that an individual tries to understand reality here and now and also tries to build cognitive-interpretative patterns. "Thus, they help him/her organize experiences in the spheres of life that are important for him/her, make the world possible to live, describe objects within one's arm's reach, build a world parallel to the existing one in one's imagination, only better, more complete, possible" ( Pilch, 2004, p.83)

From the point of view of the narrative psychology, the structure of a dream results from adjunction of the four basic components of narration, namely the storyline, characters, a problem to be solved, dramatic tension of events. It facilitates determination of certain space, in which individual stories told by the main character of the self-narration take place (Bruner, 2006). Whereas the stories initiate experiences in the process of understanding the world, they build up personal knowledge. "They are practice sessions on a simulator of events, as Singer states, and because they always contain meaning positive for an individual, they also build a positive image of tomorrow [...]" ( Pilch, 2004, p. 83). Dreams - self-narrations perform a special function, i.e. they release two motivational mechanisms. The first one resembles task motivation, which is present even after the action has been interrupted by some external circumstances and has a tendency to continual activation. The second mechanism results from auto-narrative interpretation of facts. Its cognitive premises are components of the self-narrative pattern concerning their own intentions, attitudes and feelings (Trzebiński, 2002, p. 38). Which means that an individual, when experiencing a dream understood as self-narration, first of all understands himself or herself as a subject of definite motives and feelings. This induces him or her to take appropriate actions. On the other hand, developing self-narration contributes the content of experiences of an individual in such a way that he or she really feels appropriate motives and emotions, which drive them to take up the said actions. Such a "synergic operation of both mechanisms guarantees stability of an individual's behaviour and their high resistance to external obstacles" (ibid., p. 41). Dreams-self-narrations are connected with tasks. Dreams, like tasks, contain descriptions of aspirations, plans of their implementation, description of difficulties and methods of their reduction. Dreams are lined with imagination, emotions and fantasy, whereas tasks are also 
lined with imagination, but also with reason and reality. The more an individual dreams when building up plans for fictional actions, the easier he or she draws up plans for task actions (Zimbardo, 2002).

From a cultural point of view, Homo Narrans creates his or her biography poetically occupying space. I took the term "poetic co-habitation" from an interpretation of Hölderlin's verse, "full of merits, yet poetically, man inhabits the Earth" (Heidegger, 2002, p. 168). This poetic mood refers to existence, which escapes the modern logic of order, appropriateness, common sense (Dziuban, 2012). Poetically occupy space means to dwell with sensitivity to the phenomena which are characterised by impossibility in the sense of an impossibility of defining clear boundaries between reality and imagination (Vattimo, 2012), between something and nothing, between the visible and the invisible.

\section{Dreams-self-narrations in biography of an individual - methodological frames}

A "silent methodological revolution", which involves blurring disciplinary divisions, has been going on in social sciences for the last quarter of a century. Social sciences and the liberal arts become more and more connected with one another, which is expressed by their joint concentration on interpretative, qualitative approach to research (Kubinowski, 2011, p.48). The abovementioned revolution is nothing more than a return to integral attitude towards an individual man.

Dreaming is the least investigated phenomenon in human biography, although it is a multidimensional and hence interdisciplinary phenomenon. Defining dreams by the authoress as self-narration places them in the domain of narrative-biographical studies. Narrative studies of the descriptive-interpretative type (phenomenological and hermeneutical), concerning widely understood spiritual life have a lot of raison d'êtres. Firstly, they concern unique, or extreme phenomena, such as other cultures, unusual behaviours or unusual states of mind, such as dreaming for example. Secondly, the acquired knowledge helps to develop individual and group identity. Thirdly, descriptions of positive, desired phenomena can serve as a model setting role, provide examples of coping with difficult situations (e.g. in the situation of floating - M.P.'s note), correct forms of individual and community life. Fourthly, narrations can contribute to building a social climate of tolerance and interpersonal bonds. And fifthly, they are a perfect form of psychotherapy (ibid., p. 71-72). Hence, they are particularly important for educational support provided to the elderly people, because they concern full scale of their living space. The studies are part of a wider trend, the so called studies of becoming, where as long as an individual is alive, he/she is still an unfinished biographical project (Kędzierska, 2012). 
The presented theoretical perspective determined using the methodology of qualitative research and applying the biographical method as a basic research strategy. A study of biography makes it possible not only to analyse the process structures, i.e. biographical plans of action, patterns of institutional courses of life, trajectories, biographical transformations, but also allows reconstruction of a social process. On the one hand, self-narrations hide extraordinary experiences of each individual and on the other supra-individual experiences - "patterns, socio-cultural issues and concepts can be found, which a researcher can discover and identify" (Kędzierska, 2012, p. 20).

In order to make a preliminary diagnosis of the research area, I indicated the factors which can play a significant role in the process of learning from one's biography (listed by B. Cocklin and supplemented by myself as a result of reflective consideration). As for the project discussed in this paper, the most important are dreams as self-narrations described/interpreted in a wide sociocultural context (Table 1).

Table 1. Factors affecting learning from biography

\begin{tabular}{|c|c|c|}
\hline \multicolumn{3}{|l|}{ Learning from biography } \\
\hline Biographic factors & Contextual factors & Interactive factors \\
\hline $\begin{array}{ll}\text { - } & \text { Dreams-self-narrations } \\
\text { - } & \text { One's aims in life } \\
\text { - } & \text { Outlook on life } \\
\text { - } & \text { Social background } \\
\text { - } & \text { Household situation } \\
\text { - } & \text { Social activity } \\
\text { - } & \text { Employment } \\
\text { - } & \text { Old age pension } \\
\text { - } & \text { Financial status } \\
\text { - } & \text { - Emotional status }\end{array}$ & $\begin{array}{ll}\text { - } & \text { Cultural capital } \\
\text { - } & \text { Cultural code } \\
\text { - } & \text { Educational practice } \\
\text { - } & \text { Educational } \\
& \text { opportunities }\end{array}$ & $\begin{array}{ll}\text { - } & \text { Interpersonal relations } \\
\text { (family, neighbourhood) } \\
\text { - } & \text { Interactions resulting } \\
\text { from roles player in } \\
\text { adult life } \\
\text { - Expectations resulting } \\
\text { from the status of an } \\
\text { adult } \\
\text { - Expectations resulting } \\
\text { from the status of an old } \\
\text { age pensioner }\end{array}$ \\
\hline $\begin{array}{l}\text { Critical events, Or } \\
\text { situations which turned } \\
\text { out to be turning points } \\
\text { providing qualitative } \\
\text { change in one's life, } \\
\text { such as e.g. floating }\end{array}$ & $\begin{array}{ll}\text { - } & \text { Political factors } \\
\text { - } & \text { Development of science } \\
\text { - } & \text { Intercultural experience } \\
\text { - } & \text { Experience in Inter- } \\
\text { generation } \\
\text { communication }\end{array}$ & $\begin{array}{l}\text { - Experiences related to } \\
\text { sexuality } \\
\text { - }- \text { Interactions with } \\
\text { individuals of } \\
\text { importance/ others } \\
\text { - } \\
\text { - subjective and } \\
\text { individual perception of } \\
\text { the world }\end{array}$ \\
\hline
\end{tabular}

Source: B. Cocklin ,1996, [after] M.Malewski, 1998, Teorie andragogiczne. Metodologia teoretyczności dyscypliny naukowej, $p$. 84; as well as self-reflection 
Analysis of data from narration-biographical interview "is a complicated interpretative process requiring reconstruction and (re)interpretation of the experience examined in such a way as to give the author of the narration the final right to provide sense and meaning to his or her own fate (Ligus, 2009, p. 98). All the experiences in our life, as well as dreams, as I have proved in the theoretical part, are organised in the form of stories. "Autobiographical narration shows how continuity of our "being ourselves" is created. Regardless of the fact in which point of the continuum of the biography (present-past-future) an individual places himself/herself, there are always the imaginary "now" and the imaginary "one day" present; each experience contains elements of the past, the present and the future" (Domecka, 2005, p. 235). Components of the content of autobiographical memories must be considered to obtain a detailed account (Table 2).

Table 2. Components of the content of autobiographical memories

\begin{tabular}{|c|c|c|c|}
\hline Semantic memory & Episodic memory & Declarative memory & $\begin{array}{l}\text { Non-declarative } \\
\text { memory }\end{array}$ \\
\hline $\begin{array}{l}\text { „I know” } \\
\text { Memory of facts } \\
\text { and relations among } \\
\text { facts. They have no } \\
\text { direct reference to } \\
\text { the Narrator, who } \\
\text { knows them. }\end{array}$ & $\begin{array}{l}\text { „I remember” } \\
\text { Memory of facts } \\
\text { along with their } \\
\text { temporary and } \\
\text { spatial contexts (i.e. } \\
\text { when, where and in } \\
\text { what circumstances } \\
\text { they took place). } \\
\text { The Narrator is an } \\
\text { actor and a watcher } \\
\text { of events. }\end{array}$ & $\begin{array}{l}\text { Conscious access } \\
\text { „Explicit memory” or } \\
\text { „Conscious memory” }\end{array}$ & $\begin{array}{l}\text { Its content does not } \\
\text { appear in } \\
\text { consciousness (but it } \\
\text { is very import ant for } \\
\text { dreaming - M.P.'s } \\
\text { note) }\end{array}$ \\
\hline
\end{tabular}

Source:T. Maruszewski, 2005, Pamięć autobiograficzna, pp. 21-31

General idea of "becoming" has become the basis of constructing a research project. Its objective was to acquire knowledge about implementation of dreams in biographies of the elderly individuals and learning from one's own biography. The Narrators were 20 students of the Third Age University at the J. Dlugosz University in Czestochowa. They were selected on the principle of snowball sampling. I used the method of qualitative interview with elements of narrative interview developed by S. Kvale (2004). I prepared the companion suggested by the author of the interview. The companion to the interview consisted of 3 parts and contained a set of 4 questions: question one introductory, concerned a definition of the concept of dream, question two narrative, was meant to trigger spontaneous narration concerning the subject of the study, and two successive questions - supplementary, which emphasized motives that were important for me as a researcher (their number is the question 
of the interviewer's choice). All the questions concerned directly the designated areas of research. The fundamental part of the interview was spontaneous narration which took about 1 hour. Before starting the interview, I explained the idea of the project to the Narrators. Each interview was recorded (with the Narrators' consent) and I started the analytical procedure by doing the transcription. Then, after completing the transcription, I encoded the material in compliance with the pattern of analysis of narrative interviews developed by F. Schütze (1997). Such a strategy allowed repeated analysis, which was an important element of an emerging (in-)visible world. The following interview questions proved to be very helpful: What is the sense of the word Dream do Narrators? What dreams had they implemented until the time of the interview? What were they driven by? What were their motives? Were they influenced by circumstances, important events, people, places? Do they still think about implementing their dreams now when they are old age pensioners? What conclusions have they drawn from their biography? The questions were treated as basis for answering the main question concerning educational and causative dimension of dream-self-narration in biographies of elderly individuals.

\section{Analysis of interview data - fragment}

At the very beginning, it should be emphasized that in spite of the fact that the analysis described here concerns the elderly individuals, they are in compliance with the general principle of autobiographical narration, which shows how the continuity of our "being oneself" is created. Therefore, no matter in which place of his/her biography an individual is, his/her narrations always concern to the past-present-future continuum. Components of the contents of autobiographical memories (semantic, episodic, declarative and non-declarative memory) will be essential for the complete interpretation. The analyses presented below are examples of two biographical profiles in the context of the subject that I study and they are selected fragments of the conducted study. Due to formal limitation of the text, it is impossible to present here an in-depth source material, but it will be continued in a separate paper.

The strategy of description and interpretation is based on the principle of pragmatic breakdown (Golonka, 2011, p. 174). It involves compiling individual threads, looking for contexts and attempts at contrastive comparison of different text fragments within the research areas that are of interest to the researcher.

$1 /$ General presentation of a Narrator

Narrator 1 (N1): Anna, aged 70, a retired teacher, higher education, children live abroad

Narrator 2 (N2): Helena, aged 73, a retired engineer, higher education, married, lives with her children

2/ Introductory question, concerning semantic memory

Researcher (R): What are dreams for you? 
N1: "Dreams are a form of escape from the dullness of everyday life, its problems. They take me to another better "reality". They let me look forward to the future. Life without dreams is bland and very mundane. In my opinion, it is not enough just to have dreams. Indeed, this subconscious desires gives meaning to our existence, but it is important to talk about them. I love to mix with people, talk to them, plan, help them implement their dreams if I can. One should boast about one's dreams to one's family, acquaintances, friends, to anyone who is willing to listen. An elderly person must confide her dreams to someone, it makes him feel better. Advice given by friendly people is sometimes very helpful. I found company for a journey in this way. Besides, by talking about them people strive to make their dreams come true, it does not matter what age they are. It is very important in life".

N2: "For me, dreams are tasks and goals for the future, certain potential for achieving an intended goal. They do not have to come true every time. I am a realist and I don't have unrealistic dreams. I approach dreams as assignments at school or at work. I have a definite task, I do not bite more than I can chew. Dreams are important for me. Unfortunately, I cannot afford too much, my pension is small. It's a big problem. One should not talk about one's dreams. They're only mine. Other people do not understand them, or understand them wrongly, or they can jinx them. I have never talked to anyone about my dreams. There are few people who would like to listen, others would treat them as whims, still other could treat me as an incurable kid. People are very critical. They will judge me, or even make fun of the old lady.

Narrator 1 is aware of complexity of the issue. Her statement personifies dreams as self-narrations, which have causative and educational advantages. I tell stories, therefore I am and create a better real world, woven with my dreams. There are also two dimensions revealed in her statement: the conscious and the unconscious layer of dreams. The Narrator emphasizes that becoming aware of constant desires is entering the unconscious areas, which often become impulses for action. Narrator 2 defines dreams in the category of tasks and avoids talking about her dreams. Yet, dreams do have a strong relation to tasks. Both, dreams as well as tasks contain description of aspirations, plans of their implementation, description of difficulties and methods for reducing them. Narrator 2 does not notice the value of unconscious processes in creating dreams. Instead, she unconsciously operates with a code in the form of irrational superstition dreams cannot be revealed, because they may be jinxed. This may be a permanent restraint for dreams understood as self-narrations.

3/ The question initiating free narration, concerning episodic memory.

B: How do you perceive the presence and implementation of dreams in your life, particularly now that you are retired?

N1: I try to make my dreams come true and until now I have realized some of them. Each age has its pleasant moment and the sense of fulfilment instils 
optimism in me. Dreams of my childhood and early youth more than met my expectations. I have fond memories of the time. My parents protected me against the hardships of life. I remember that when I was a child, I spent hours on my tree in the garden looking at the clouds, which arranged themselves into different shapes. I gave them names and thought up different stories. I have always been a heroine of my imagined stories, e.g. I sailed on a ship, I glided on wings and travelled on an elephant. They were worlds of my dreams and wellbeing. When I recall the memory now, I miss Nature. I would gladly get rid of contacts with the civilised world and live in primitive conditions, but in according to the primitive instinct. This is why I travel a lot to different exotic countries, but my true love is Africa. Generally, getting to know the world, people, cultures is making my dreams come true. There is still one more which I want to come true, a journey around the world. Nowadays, when I'm retired, I have a lot of free time, fewer duties, I can go anywhere I want to go. Of course, I attend the UTA. It is the place where I want to catch up with the world. I learn foreign languages, information technologies, I read a lot, listen to interesting lectures, I make my dreams come true".

N2: Most of my dreams are difficult to realize, of course due to financial reasons. Yet, I think it is a wonderful thing to make your dreams come true, but unfortunately, after 32 years of work, I can only afford to have them. They are also difficult to realize due to my age as many things are unbecoming of an elderly person. One can be ridiculed. Basically, I have no unreasonable dreams. During the Nazi occupation, I had very traumatic experiences when I was a child. My father died in the war, in 1944, and I was brought up by my mother. I dreamed about full, large, happy family. This issue became my priority in my adult life. I do have a large, happy family. I don't want to recall the times of my youth either. I was a half-orphan and an only child. I had to work hard. I remember that in my youth I dreamt about a claret-coloured coat, but I never had enough money to buy one. Now, I just hate the colour. To be quite frank, dreams of my childhood are unreal for me, and those from my youth..., I just lack the strength and inspiration. Now that I am retired, my dreams have partly come true. I can take Sunday sightseeing trips to the country with my husband, I can spend time with my grandchildren, I love it. I am also a student of the UTA. It's my second home, my second, grand family. I can relax here.

Both Narrators retrace the chronological courses of their lives. In their narrations about dreaming, each period was and still is of great importance. However, for each of them experiences of the said periods have a completely different educational overtone. To Narrator 1 childhood appears as a carefree, safe, self-centred time. Hence her cultural code for being free, crossing worlds in her dreams and now in reality when travelling. Transitory nature of a moment has become the driving force to finding her life very fulfilling. Apart from that, the educational dimension of contacts with nature during her childhood was transformed into ecological awareness and manifested longing for the lost 
paradise. The childhood of Narrator 2, full of suffering, anxiety about her family was transformed into her dream of her mission to be the prop of a family. The key model-creating symbol here was the image of her mother as the person maintaining the household after her father's death. The Narrator dreamed about her vocation to be a good wife and mother. The important aspect here is her attachment to place where she was deeply-rooted, the need to establish a home. In both cases, the Narrators talk about their vocation, though the first one talks about her vocation to be herself, and the other about her vocation to perform her social role. Their present family situation is not insignificant for realization of their dreams. Narrator 1 is a free person, whose children live abroad, whereas Narrator 2 is married, with a large multi-generation family living in close vicinity. Their financial situation is an interesting motive in realization of their dreams. An unattached retired teacher never mentions any difficulties, whereas the other Narrator also has dreams, but their realization is impossible, because she can only afford to have dreams. The motives of carefree childhood of Narrator 1 and poverty that Narrator 2 experienced are certainly very important. In my opinion, talking about her dreams by Narrator 1 gives basis for crossing the stages of life and heading towards constructing "biography of one's soul" (Lani-Bayle, 2014). In the case of Narrator 2, who refrains from talking about her dreams, her lifeline is strongly institutionalized, full of suffering, minimalism and acceptance of what the fate brings (Beck, 2004). In the case of the first person, old age is not an obstruction in thinking about dreams, in the case of the other person there is a barrier in the form of a cultural standard - at this age it is unbecoming. Still, they are both students of the UTA, though their motives are different. Narrator 1 personifies the model of the "flexible youth" (T. Buliński, 2002), where the stage of retirement is still an educational challenge for realization of one's dreams - the Narrator wants to catch up with the world by acquiring new skills. For Narrator 2, the UTA is a second home. She does not want to catch up, but she wants to relax in accordance with the archetype of quiet old age of a retired person, but does not want to be alone.

\section{3/ Supplementary questions}

B: What are particular personal experiences (events, places) in your biography, which influenced realization of your dreams in personal life and career?

N1: As for my career, it started when I was very young, [...], a made my younger brothers and sister sit on chairs, stools, I created a small class in the room, which transformed into an idea of becoming a teacher. I wanted very much to be a teacher. I remember that I dreamt about having glasses and a pointer, just like my own teacher. I kept talking about it. I pilfered glasses from my mother. She was a teacher, too, and my father whittled a pointer for me from a piece of wood. As for my personal experience, I remember that one day, when I was a teenager, I felt very badly. It turned out that I had serious pneumonia. I 
had a fever and I raved. I suffered from hallucinations. One of them I remember even today. I was walking in the fields pushing aside ears of grain when suddenly a bee landed on a palm of my hand. I was frightened, but when I turned my hand I saw the bee transfer into a beautiful ring with a piece of amber on one of my fingers. Then I realized (in my sleep) that everything is possible, that the impossible becomes possible. When I recovered, I returned to this thought every day.

N2: I come from a family with a craft tradition. My grandparents had a small locksmith's shop. My parents also owned it for a short time. After my father's death everything collapsed. My grandfather did not miss a single opportunity to tell me, and I was his only grandchild, that I have to take everything over. I was a girl and I was interested in other things. I liked drawing. My grandfather used to say, you have to be an engineer. Engineers also draw. I loved my granddad very much, he was a father substitute for me. When I grew up, I started to study engineering, although this type of drawing is completely different. I think that a significant event that set the course of my personal life was my father's death. It changed me very much. I was a small girl and I thought that I have to be tough, like a boy, and I have to help my mother like a man. And then I kept growing up with such manliness. I approached my life as a set of tasks. I met my husband when I was a student. He is also an engineer. We ran the small workshop together. I was the manager. My grandfather's dream came true. Then, transformation came and everything collapsed again.

The environment of primary socialization is the basic source of cultural capital of individuals, their habitus, "through which social reality is internalized and treated individually, providing compliance between objectively existing opportunities and subjectively displayed aspirations" (Szlachcicowa, 2005, p. 274). Habitus, which is a socially acquired and consolidated system of thinking and acting differentiates chances of making dreams come true and the selection of style of constructing one's biography. The Narrators come from different social environments. If it is assumed that the criterion of social status is the level of education, as well as the practised profession - then the first one comes from a family of pre-war teaching tradition, which was considered to be of high social status, and the other from a family of pre-war craft tradition, which meant lower social status. Significant personalities for the first Narrator were, in the first case, her mother - a teacher, in the second case, her father - a craftsman. Significant events were the critical moments which consolidated different imperatives for her future life. The serious illness of the first Narrator, aided by a magic space (dreaming), created an internal belief that the impossible can become possible and it is determined by herself. In the case of the second Narrator, her experience connected with her father's death determined her fate and her conviction that she cannot influence anything. Places from which they both started embodied, to a large extent, their long-lasting bodily and mental 
predispositions (Demetrio, 2009). These different starting points determined their different understanding of the presence and realization of dreams in their biographies.

B: What emotions and feelings well up within you when you talk about your dreams? What have you learnt from your biography?

N1: I strongly believe that dreams have created my world, many worlds. I am always accompanied by the sense of happiness and satisfaction, when I return from a dream trip of mine. I don't abide in the world of dreaming, but I choose a specific strategy of acting, which means that I learn how to make my dream come true.

N2: I am convinced that talking about dreams is naive. This is why I approach it with a tongue in my cheek. I am ashamed to talk about my dreams for fear that someone might laugh at me. In my life, I set realistic goals for myself, according to the opportunities created by the external circumstances.

Both Narrators are accompanied by emotions, but they are completely different. Narrator 1 displays an intense feeling of happiness, joy, selffulfilment, whereas Narrator 2 is dominated by the feeling of apprehension and embarrassment. In the case of Narrator 1, positive experiences act as accelerators in her aspirations to make her dreams come true, whereas for Narrator 2 they act as restraining factors, inhibitors. Narrator 1 approaches realization of her dreams as something that happens in two stages, first in her mind and then in reality. Still, what happens on the mental level is developing educational strategy of learning. She is the architect of her fortune, which is exactly what a reflection on her own biography has taught her. In the case of Narrator 2, imagination gives in to rational calculation, intellectual speculation about goals than are possible to be implemented. Narrator 2 has learnt from her biography that her assessment of plans is often externally motivated.

\section{Conclusion}

The data obtained from interviews were analysed on two planes - vertical and horizontal. The vertical analysis was a thematic analysis and served isolating of the main motives as the narrations were constructed around issues concerning vital areas of life of the Narrators, i.e. family home, education, career, retirement. Identification of the thematic groups provided important information about biographical factors (conscious and unconscious), which influenced the process of constructing dreams. However, vertical analysis is not a sufficient analysis as it reduces biographical narrations to a set of statements of standard tinge. It becomes a story about vocation. The horizontal analysis concerned determining theoretical codes and involved constant comparison. Each hypothesis generated from the thematic analysis and code integration was consolidated in reference to the entire narration of each interviewed person and compared to narrations of the others. It was, therefore, examined in a wide 
socio-cultural perspective (of contextual, interactive factors), which allowed to describe successive patterns of reasoning and conscious acting, as well as unconscious one.

The analyses of study fragments quoted above make it possible to put forward a cautious final conclusion. The Narrators are aware of the educational and causative dimensions of dreams in their biographies. Yet those who tell about their dreams and those who remain silent on this point emphasize different elements of their stories. In the first case, it is an experience directed more towards existential learning, whereas in the other case it is an experience directed more towards institutionalized learning. The elderly people, who have reached the last stage of their institutionalized biography - the stage of retirement - should not abandon an important part of their living space. Those who have, or those who have insufficiently made use of the space, should be provided support in revealing the (in-)visible space, encourage them to talk about their dreams and to construct "biography of the soul".

\section{References}

Barthes, R. (1968). Wstęp do analizy strukturalnej opowiadań. Pamiętnik Literacki, 4, 325425

Beck, U. (2004). Społeczeństwo ryzyka. W drodze do innej nowoczesności. Warszawa: Wyd. Naukowe Scholar

Berger P. , Luckmann T. (2010). Spoleczne tworzenie rzeczywistości. Warszawa: PWN

Bron, A. (2000). Floating as an Analytical Category in the Narratives of Polish Immigrants

to Sweden. In: Szwejkowska -Olsson E., Bron A. (Eds.) Allvarig debatt och rolig lek.

En festskrift tillagnad A. Nils Uggla. Szwecja: Uppsala University

Bruner, J. (2006). Kultura edukacji. Kraków: Universitas

Buliński, T. (2002). Człowiek do zrobienia. Poznań: Wydawnictwo Poznańskie

Burszta, W., Kuligowski W. (1998) Antropologia kultury. Tematy, teorie, interpretacje. Poznań: Wyd. Zysk i S-ka

Burszta, W. (2008). Świat jako więzienie kultury. Pomyślenia. Warszawa: PIW

Burzyńska, A., Markowski, M. (2006). Teorie literatury XX wieku. Podręcznik. Kraków: Znak

Cocklin, B. (1996). Applying Qualitative Research to Adult Education: Reflections upon Analytic Processes. Studies in the Education of Adults. Vol.28,1

Covey, S. (1998). 7 nawyków skutecznego działania. Poznań: Rebis

Czapiński, J. (2005) Psychologia pozytywna. Warszawa: PWN

Demetrio, D.(2009) Pedagogika pamięci, Łódź: Wyd. AHE

Domecka, M. (2005),Konstrukcja kariery, konstrukcja biografii, konstrukcja siebie. Narracje autobiograficzne ludzi biznesu. In: Konecki K., Kasperczyk A. (Eds.) Procesy tożsamościowe. Symboliczno-interakcyjny wymiar konstruowania tadu $i$ nieładu spotecznego., (pp. 138-149). Łódź: Wyd. Naukowe Uniwersytetu Łódzkiego

Dziuban, Z. (2012). Oikofobia jako doświadczenie kulturowe. Kultura i historia, 2

Foucault, M. (2000) . Historia seksualności. Warszawa: Czytelnik

Golonka, J. (2011). Uczenie się z biografii - indywidualna koncepcja wykorzystania wywiau biograficznego. In: Dubas E., Świtalski W. (Eds.) Uczenie się z (własnej) biografii.,(pp. 163-182). Łódź: Wyd. Naukowe Uniwersytetu Łódzkiego 


\section{SOCIETY. INTEGRATION. EDUCATION. Volume IV}

Hałas, E. (1991). Znaczenia i wartości społeczne. O socjologii Floriana Znanieckiego. KUL, Lublin: KUL

Heidegger, M. (2002). Odczyty i rozprawy. Kraków: Wydawnictwo Baran i Suszczyński

Janion, M. (1996). Czy będziesz widziat, co przeżyłeś, Warszawa: Sic!

Jarvis, P. (2006). Towards a Comprehensive Theory of Human Learning, Volume 1, London: Routledge

Kędzierska, H. (2012). Między powołaniem a strategią maksymalizacji zysków-przemiany dróg wyboru zawodu nauczyciela. In: Gołębniak D.B., Kwiatkowska H. (Eds.) Nauczyciele. Programowe (nie)przygotowanie (pp. 15-42). Wrocław: Wyd. Naukowe DSW

Kubinowski, D. (2011.) Jakościowe badania pedagogiczne. Filozofia, Metodyka, Ewaluacja. Lublin: Wyd. Uniwersytetu UMCS

Kundrea, M. (1991). Sztuka powieści. Warszawa: PIW

Kvale, S. (2004). InterViews. Wprowadzenie do jakościowego wywiadu badawczego. Białystok: Trans Humana

Lani-Bayle, M. (2014). Le temps des histoires. Vie sociale et traitements, 1, 19-25

Ligus, R. (2009). Biograficzna tożsamość nauczycieli. Wrocław: Wyd. Naukowe DSW

Łukaszewicz, R. (2012). Inna edukacja. Biografia drogi. Wrocław:WIE

Malewski, M. (1998). Teorie andragogiczne. Metodologia teoretyczności dyscypliny naukowej. Wrocław: Wyd. Uniwersytetu Wrocławskiego

Maruszewski, T. (2005), Pamięć autobiograficzna. Gdańsk: GWP

Mendel, M. (2006). Pedagogika miejsca. Wrocław: Wyd. Naukowe DSW

Nowak -Dziemianowicz, M. (2011). Narracja - Tożsamość - Wychowanie. Perspektywa przejścia i zmiany. Teraźniejszość - Człowiek - Edukacja, 3 (55), 37-53

Pilch, T. (2004). Encyklopedia Pedagogiczna XXI wieku. Warszawa; Wydawnictwo Żak

Popper, K. (1997).W poszukiwaniu lepszego świata. Warszawa: Książka i Wiedza

Semków, J. (2000). Wielość wymiarów przestrzeni życiowej ludzi w III wieku. In: Dzięgielewska M ( Eds.) Przestrzeń życiowa i społeczna ludzi starszych. (pp. 27-34). Łódź: Akademickie Towarzystwo Andragogiczne

Schütze, F. (1997). Trajektorie cierpienia jako przedmiot socjologii interpretatywnej. Studia Socjologiczne, 1, 11-50

Siarkiewicz, E. (2010) Poradnictwo performatywne i inne formy pomocy w zdarzeniach krytycznych i doświadczeniach granicznych. In: Olejarz M. (Eds.) Dyskursy młodych andragogów. (pp. 265-285). Zielona Góra:Wyd. Uniwersytetu Zielonogórskiego.

Słowik, A. (2012). Trajektoria uczenia się emigrantów w sytuacji doświadczania zawieszenia ( floating). Ku rozumieniu poradnictwa międzykulturowego. Studia Poradoznawcze , 2, 48-68

Sroczyński, W. (2006). Środowisko niewidzialne w andragogice. Kultura i edukacja, 1, 74-89

Szlachcicowa, I. (2005). Tożsamość biograficzna jako strategia życia -ciągłość czy zmiana. In: Hałas, E., Konecki K. (Eds.) Konstruowanie jaźni i społeczeństwa. Europejskie warianty interakcjonizmu symbolicznego. (pp. 268-290 ). Warszawa: Wyd. Naukowe scholar

Trzebiński J. (2002). Narracja jako sposób rozumienia świata. Gdańsk: GWP

Vattimo, G. (2011). Poza interpretacja. Kraków: Universitas

Zimbardo P. (2002) Psychologia i życie, Warszawa: PWN 